\title{
Elevated serum neutrophil elastase is related to prehypertension and airflow limitation in obese women
}

\author{
Mervat M El-Eshmawy ${ }^{1}$,Eman H El-Adawy ${ }^{1 *}$, Amany A Mousa ${ }^{1}$, Amany E Zeidan³, Azza A El-Baiomy², \\ Elham R Abdel-Samie², Omayma M Saleh ${ }^{1}$
}

\begin{abstract}
Background: Neutrophil elastase level/activity is elevated in a variety of diseases such as atherosclerosis, systolic hypertension and obstructive pulmonary disease. It is unknown whether obese individuals with prehypertension also have elevated neutrophil elastase, and if so, whether it has a deleterious effect on pulmonary function. Objectives: To determine neutrophil elastase levels in obese prehypertensive women and investigate correlations with pulmonary function tests.

Methods: Thirty obese prehypertensive women were compared with 30 obese normotensive subjects and 30 healthy controls. The study groups were matched for age. Measurements: The following were determined: body mass index, waist circumference, blood pressure, lipid profile, high sensitivity C-reactive protein, serum neutrophil elastase, and pulmonary function tests including forced expiratory volume in one second $\left(F E V_{1}\right)$, forced vital capacity (FVC) and $\mathrm{FEV}_{1} / \mathrm{FVC}$ ratio.

Results: Serum neutrophil elastase concentration was significantly higher in both prehypertensive (405.8 \pm $111.6 \mathrm{ng} / \mathrm{ml})$ and normotensive $(336.5 \pm 81.5 \mathrm{ng} / \mathrm{ml})$ obese women than in control non-obese women $(243.9 \pm$ $23.9 \mathrm{ng} / \mathrm{ml}$ ); the level was significantly higher in the prehypertensive than the normotensive obese women. FEV1, FVC and FEV1/FVC ratio in both prehypertensive and normotensive obese women were significantly lower than in normal controls, but there was no statistically significant difference between the prehypertensive and normotensive obese women. In prehypertensive obese women, there were significant positive correlations between neutrophil elastase and body mass index, waist circumference, systolic blood pressure, diastolic blood pressure, total cholesterol, triglyceride, low density lipoprotein cholesterol, high sensitivity C-reactive protein and negative correlations with high density lipoprotein cholesterol, FEV1, FVC and FEV1/FVC.
\end{abstract}

Conclusion: Neutrophil elastase concentration is elevated in obese prehypertensive women along with an increase in high sensitivity C-reactive protein which may account for dyslipidemia and airflow dysfunction in the present study population.

\section{Background}

The seventh report of the Joint National Committee (JNC-7) proposed a new classification distinguishing between individuals with normal blood pressure and established hypertension. The report categorized people with systolic blood pressure between 120 and $139 \mathrm{~mm}$

\footnotetext{
* Correspondence: eman.eladawy@yahoo.com

'Internal Medicine Department, Specialized Medical Hospital, Faculty of

Medicine, Mansoura University, Mansoura, Egypt

Full list of author information is available at the end of the article
}

$\mathrm{Hg}$ or diastolic blood pressure between 80 and $89 \mathrm{~mm}$ Hg as having 'prehypertension' [1]. Data from the 1999 and 2000 National Health and Nutrition Examination Survey (NHANES III) suggested that the prevalence of prehypertension among adults in the United States was approximately $31 \%$ [2]. Prehypertension is a risk factor for overt hypertension [3] and future cardiovascular disease events [4]. Prospective observational studies suggest the risk of cardiovascular death begins at $115 / 75 \mathrm{~mm}$

\section{Biomed Central}

(c) 2011 El-Eshmawy et al; licensee BioMed Central Ltd. This is an Open Access article distributed under the terms of the Creative Commons Attribution License (http://creativecommons.org/licenses/by/2.0), which permits unrestricted use, distribution, and reproduction in any medium, provided the original work is properly cited. 
$\mathrm{Hg}$ and doubles for every 20/10 $\mathrm{mm} \mathrm{Hg}$ increment in a linear fashion [5].

Leukoprotease activity was first described early in the $20^{\text {th }}$ century but human neutrophil elastase (NE) was only identified relatively recently [6]. Intracellular NE is a key effector molecule of the innate immune system, with potent antimicrobial activity against Gram negative bacteria [7], spirochetes [8] and fungi [9]. Its bestknown extracellular manifestation is connective tissue digestion. NE is capable of digesting virtually every type of matrix protein, including elastin [10]. Because of its unique elastic recoil properties, elastin is vital for conferring elasticity on arteries, lungs, ligaments and skin [11]. Biologically, NE is considered a secretagouge for cytokines [12] and a modulator of inflammation [13]. Alpha-1 antitrypsin is the major specific inhibitor for NE [14]. Alpha-1 antitrypsin is an acute phase protein derived from liver and its concentration rises during inflammation; it inhibits NE to prevent tissue injury in target organs [15]. Other protease inhibitors ordinarily present in human serum are $\alpha_{1}$-antichymotrypsin and $\alpha_{2}$-macroglobulin [16].

Elevation of NE levels/activity has been demonstrated in a variety of pathological conditions including cystic fibrosis [17], acute respiratory distress syndrome, bronchiectasis, chronic obstructive pulmonary disease [18], type2 diabetes mellitus, atherosclerosis [19], aortic stiffness and systolic hypertension [20]. Such changes have been explained by a possible protease/anti-protease imbalance. This imbalance might be due to an increased elastase load following neutrophil influx, a reduction in the levels or activity of the circulating inhibitors of this enzyme, or increased non-apoptotic neutrophil death [21].

It is unknown whether obese individuals with prehypertension also have elevated NE, and if so, whether it has a deleterious effect on pulmonary function. The aim of the present study was to investigate the level of serum elastase in obese prehypertensive women and to investigate correlations with pulmonary function tests.

\section{Methods}

Ninety females were enrolled in the study, divided into three groups (Table 1). Group 1 included 30 obese prehypertensive women. Group 2 included 30 obese normotensive women. Group 3 included 30 non-obese, age-matched normotensive women (control group). The mean ages were $33.5 \pm 7.7,34.4 \pm 9$ and $36.5 \pm 5.2$, respectively. The obese patients were attending obesity clinics at the Specialized Medical Hospital. All patients signed an informed consent to be included in our study. The study was approved by the local ethical committee of Mansoura University Hospital, Internal Medicine Department.
Table 1 Subjects characteristics

\begin{tabular}{|c|c|c|c|}
\hline Characteristics & $\begin{array}{l}\text { Group1 } \\
(n=30)\end{array}$ & $\begin{array}{l}\text { Group2 } \\
(\mathrm{n}=30)\end{array}$ & $\begin{array}{l}\text { Group3 } \\
(\mathrm{n}=30)\end{array}$ \\
\hline Age (years) & $33.5 \pm 7.7$ & $34.4 \pm 9$ & $36.5 \pm 5.2$ \\
\hline BMI $\left(k g / m^{2}\right)$ & $43.4 \pm 9.4^{*}$ & $38.9 \pm 4.309$ & $22.8 \pm 1.83$ \\
\hline WC $(\mathrm{cm})$ & $115.1 \pm 15.4^{*}$ & 103.8 .6 .69 & $72.6 \pm 4.6$ \\
\hline $\mathrm{SBP}(\mathrm{mm} \mathrm{Hg})$ & $129.5 \pm 5.5^{*}$ & $118 \pm 49$ & $118.7 \pm 6.3$ \\
\hline DBP (mm Hg) & $83.1 \pm 2.5^{*}$ & $78 \pm 49$ & $76 \pm 4.98$ \\
\hline FH of HTN & $80 \%$ & $50 \%$ a & $23.3 \%$ \\
\hline hs-CRP ( $\mu \mathrm{g} / \mathrm{ml})$ & $3.1 \pm 0.6^{*}$ & 2. $3 \pm 10$ & $1.8 \pm 0.6$ \\
\hline TC (mg \%) & $220.9 \pm 38.2^{*}$ & $180.2 \pm 20.6$ & $157.6 \pm 19.04$ \\
\hline TG (mg \%) & $206.4 \pm 16.4^{*}$ & $133.7 \pm 31.6 a$ & $95.8 \pm 31.07$ \\
\hline LDL-c (mg \%) & $142.9 \pm 26.2^{*}$ & $117.7 \pm 20.20$ & $95.5 \pm 19.8$ \\
\hline HDL-c (mg \%) & $37.8 \pm 5.3^{*}$ & $42.8 \pm 6.50$ & $52.9 \pm 2.1$ \\
\hline
\end{tabular}

Data are expressed as mean \pm standard deviation.

${ }^{*} p \leq 0.05$ : group 1 vs. group 3; ap $\leq 0.05$ : group 2 vs. group 3 ; $9 p \leq 0.05$ : group 1 vs. group 2 .

Group 1: obese prehypertensive women.

Group 2: obese normotensive women.

Group 3: normal controls.

BMI: Body mass index.

WC: Waist circumference.

SBP: Systolic blood pressure.

DBP: Diastolic blood pressure.

FH of HTN: Family history of hypertension.

hs-CRP: High sensitivity C-reactive protein.

TC: Total cholesterol.

TG: Triglyceride.

LDL-c: Low density lipoprotein cholesterol.

HDL-c: High density lipoprotein cholesterol.

Blood pressure was categorized according to the JNC7 (1). Normal blood pressure was defined as not being on antihypertensive medication and having systolic blood pressure less than $120 \mathrm{~mm} \mathrm{Hg}$ and diastolic blood pressure less than $80 \mathrm{~mm} \mathrm{Hg}$. Prehypertension was defined as not being on antihypertensive medication and having a systolic blood pressure of 120-139 mm Hg or diastolic blood pressure of $80-89 \mathrm{~mm} \mathrm{Hg}$ on three occasions. Blood pressure was taken in the sitting position after $10 \mathrm{~min}$ rest using a random-zero sphygmomanometer.

All participants were subjected to thorough medical history and clinical examination, and anthropometric measurements were performed as follows: height was measured to the nearest $0.5 \mathrm{~cm}$; body weight was measured to the nearest $0.1 \mathrm{~kg}$; body mass index (BMI) was calculated as weight $/$ height ${ }^{2}\left(\mathrm{~kg} / \mathrm{m}^{2}\right)$. Waist circumference (WC) was measured at the highest point of the iliac crest.

\section{Assay}

Serum total cholesterol (TC), triglyceride (TG), and high density lipoprotein cholesterol (HDL-c) were assayed by commercially available kits. Low density lipoprotein cholesterol (LDL-c) was calculated according to 
Friedewald et al. [22]. Serum elastase was measured by ELISA, supplied by Immunodiagnostic AG StubenwaldAllee 8 Ad-64625 Bensheims, according to Oremek etal. [23]. High sensitivity CRP (hs-CRP) was estimated using an immunoenzymometric assay supplied by Monobind Inc., Lake Forest, CA 92630 USA, according to Kimberly et al. [24].

\section{Pulmonary Function Tests}

Spirometry was performed according to the criteria of the ATS using a computerized spirometery apparatus (Jager Spirometery), and the following parameters were determined: forced vital capacity (\%FVC), forced expiratory volume in the first second $\left(\% \mathrm{FEV}_{1}\right)$, and $\mathrm{FEV}_{1} / \mathrm{FVC}$ ratio [25].

\section{Statistics}

Excel and SPSS packages version 10 (spss, inc., Chicago, IL, USA) were used for the statistical analysis of data. The data were expressed as mean $( \pm)$ SD for continuous data and frequency and proportion for categorical data. For continuous data, Student's t-test was used to compare two groups. A chi square test was used to compare categorical data. Correlation coefficients were calculated to evaluate associations between variables. $\mathrm{P}$ value $=$ 0.05 was considered as significant at a $95 \%$ confidence interval.

\section{Results}

Baseline characteristics of the three groups are given in Table 1. Obese prehypertensive women (group 1) had significantly higher BMI, WC, systolic and diastolic blood pressure, hs-CRP, TC, TG and LDL than groups 2 and 3. HDL-c was significantly lower in group 1 than groups 2 and 3. Obese normotensive women had significantly higher BMI, WC, hs-CRP, TC, TG and LDL-C than normal controls. HDL-c was significantly lower in group 2 than group 3. Eighty percent of obese prehypertensive women had positive family histories of hypertension, $50 \%$ in group 2 and $23 \%$ in group 3.

Serum elastase levels were significantly higher in group $1(405.8 \pm 111.6 \mathrm{ng} / \mathrm{ml})$ than groups $2(336.5 \pm$ $81.5 \mathrm{ng} / \mathrm{ml})$ and $3(243.9 \pm 23.9 \mathrm{ng} / \mathrm{ml}), \mathrm{p}=0.008$ and $\mathrm{p}<0.001$ respectively. They were also higher in group 2 than group $3(\mathrm{p}=0.001)$ (Figure1).

$\mathrm{FEV}_{1}$ and FVC were significantly lower in group 1 $(84.6 \pm 6 ; 75.6 \pm .4 .1)$ and group $2(86.6 \pm 6.9 ; 76.2 \pm$ $6.5)$ than group $3(91 \pm 3.4,93.4 \pm 3.6)$ but there was no statistically significant difference between groups 1 and 2 ( $\mathrm{p}=0.08, \mathrm{p}=0.7$, respectively). The $\mathrm{FEV}_{1} / \mathrm{FVC}$ ratio was significantly lower in group $1(77.7 \pm 8.6)$ and group $2(79.4 \pm 11)$ than group $3(87.8 \pm 2.7)$ but this reduction did not reach the obstructive limit $(<70 \%)$.
There was no significant difference in $\mathrm{FEV}_{1} / \mathrm{FVC}$ between groups 1 and 2, p = 0.51 (Table 2).

The correlations between serum elastase level and other parameters in group 1 are shown in Table 3 . The serum elastase levels were positively correlated with BMI, WC, SBP, DBP, TC, TG ( $\mathrm{r}=0.62, \mathrm{p}=0.009)$, LDL-c and hs-CRP $(r=0.7, p<0.001)$, and negatively correlated with $\mathrm{HDL}, \mathrm{FEV}_{1}, \mathrm{FVC}$ and $\mathrm{FEV}_{1} / \mathrm{FVC}$.

\section{Discussion}

There are clear epidemiological links between obesity and hypertension; obesity is probably the most important modifiable risk factor contributing to hypertension [26]. Weight gain after age 20 substantially increases the risk for prehypertension in non-hypertensive individuals, while weight loss significantly lowers the risk [27]. With respect to specific risk factors, the risk ratio for obesity is greater in prehypertensive than normotensive subjects $[28,29]$. Interestingly, a recent large-scale populationbased study demonstrated that abdominal obesity was the strongest independent predictor of lung function impairment [30].

The current study examined, for the first time, the relationship between serum elastase and prehypertension in obese women and correlated its level with pulmonary function tests. The main finding was that the serum elastase level was significantly higher in obese prehypertensive women than obese normotensive women and normal controls.

These results parallel those of Niccoloff and Christova [31], who found significant elevation of elastin-derived protein (EDP) in obese hypertensive children with a family history of arterial hypertension, and the level was significantly higher than in obese non-hypertensive children with a family history of hypertension, obese non-hypertensive children without family history of hypertension, and healthy non-obese children. Obese non-hypertensive children with a family history of hypertension had significantly higher EDP than controls, whereas obese non-hypertensive children with no family history of arterial hypertension did not differ from controls. Also, using microangiopathy, Nicooloff et al. [32] found significantly higher concentrations of elastin peptides in obese hypertensive children and diabetic children than in controls. Piwowar et al. [33] demonstrated significantly higher plasma elastase in obese diabetic patients than in lean ones. In contrast, Adeyemi et al. [34] found that the plasma elastase levels (determined by ELISA) in obese individuals did not differ significantly from those in lean healthy controls.

Experimental models of hypertension in animals suggest that enhanced mechanical stress induced by acutely raising blood pressure increases the synthesis of elastin 


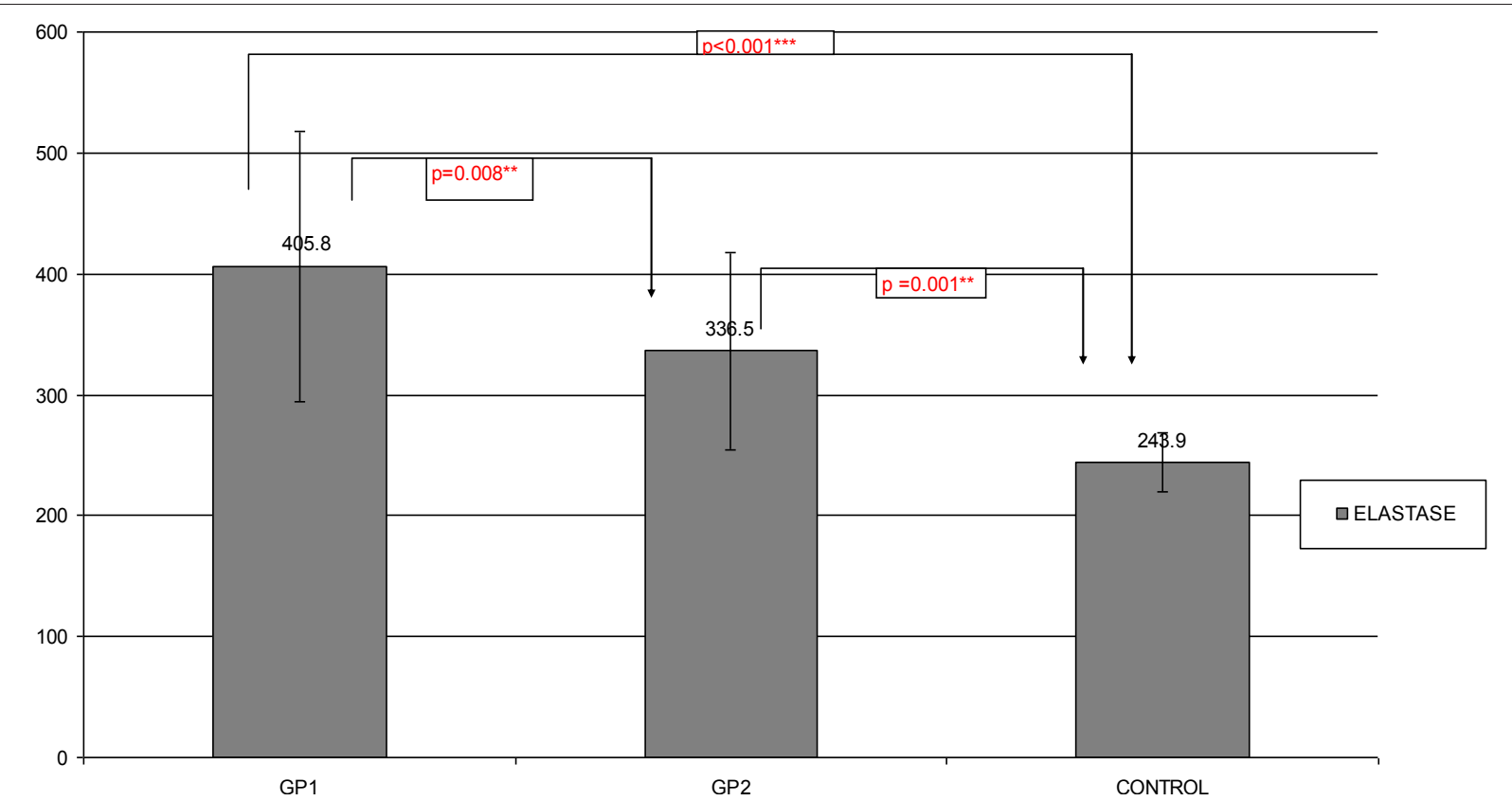

Figure 1 Serum elastase in the studied groups. ${ }^{* *} p<0.01{ }^{* *} p<0.001$ GP1: obese prehypertensive women GP2: obese normotensive women.

and collagen in arteries, and this in turn elevates the synthesis of matrix metalloprotinase-9 [35]. Arterial hypertension is connected with the loss of elasticity, increasing rigidity of the arterial wall and an abnormal increase in collagen/elastin degradation in obese patients with arterial hypertension [31].

A major mechanism responsible for obesity-associated hypertension is inflammation; this increases insulin resistance, which in turn leads to obesity while perpetuating diabetes, high BP, and dyslipidemia [36]. Abnormalities in circulating markers of inflammation, such as CRPs, interleukin- 6 and TNF- $\alpha$ are more common in prehypertension than normotension [37,38]. Mania et al. [39] speculated that elastase may be used as a nonspecific indicator to screen inflammation and infection. Cardiovascular complications of obesity are associated with elevated degradation of elastic tissue [40]. It can be

Table 2 Pulmonary function in the three groups

\begin{tabular}{llll}
\hline Pulmonary function test & Group 1 & Group 2 & Group 3 \\
\hline FEV $_{1}$ & $84.6 \pm 6^{*}$ & $86.6 \pm 6.90$ & $91 \pm 3.4$ \\
FVC & $75.6 \pm .4 .1^{*}$ & $76.2 \pm 6.50$ & $93.4 \pm 3.6$ \\
$\mathrm{FEV}_{1} / \mathrm{FVC}$ & $77.7 \pm 8.6^{*}$ & $79.4 \pm 110$ & $87.8 \pm 2.7$
\end{tabular}

Data are expressed as mean \pm standard deviation.

* $p \leq 0.05$ : group 1 vs. group 3; a $p \leq 0.05$ : group 2 vs. group 3 .

Group 1: obese prehypertensive women.

Group 2: obese normotensive women.

Group 3: normal controls.

$\mathrm{FEV}_{1} \%$ : Forced expiratory volume in one second.

FVC\%: Forced vital capacity. inferred that proteolytic enzymes are actively involved in the remodeling of vessel walls, causing stiffness in them and contributing to the development of hypertension [41].

Table 3 Correlation between serum elastase and clinical and metabolic parameters in obese prehypertensive women

\begin{tabular}{lll}
\hline Characteristics & R & P-value \\
\hline BMI $\left(\mathbf{k g} / \mathbf{m}^{2}\right)$ & 0.37 & $0.05^{*}$ \\
WC $(\mathbf{c m})$ & 0.53 & $0.01^{* *}$ \\
SBP $(\mathbf{m m ~ H g})$ & 0.4 & $0.02^{*}$ \\
DBP $(\mathbf{m m ~ H g})$ & 0.48 & $0.01^{* *}$ \\
TC $(\mathbf{m g} \%)$ & 0.49 & $0.03^{*}$ \\
TG $(\mathbf{m g} \%)$ & 0.62 & $0.009^{* *}$ \\
LDL-c $(\mathbf{m g} \%)$ & 0.45 & $0.02^{*}$ \\
HDL $(\mathbf{m g} \%)$ & -0.51 & $0.03^{*}$ \\
hs-CRP $(\boldsymbol{\mu g} / \mathrm{ml})$ & 0.7 & $<0.001^{* * *}$ \\
FEV $\%$ & -0.28 & 0.13 \\
FVC $\%$ & -0.17 & 0.37 \\
FEV $/$ FVC & -0.28 & 0.32 \\
\hline
\end{tabular}

${ }^{*} \mathrm{p} \leq 0.05{ }^{* *} \mathrm{p} \leq 0.01{ }^{* * *} \mathrm{p} \leq 0.001$.

BMI: Body mass index.

WC: Waist circumference.

SBP: Systolic blood pressure.

DBP: Diastolic blood pressure.

TC: Total cholesterol.

TG: Triglyceride.

LDL-c: Low density lipoprotein cholesterol.

HDL-c: High density lipoprotein cholesterol.

hs-CRP: High sensitivity C-reactive protein.

FEV1\%: Forced expiratory volume in one second.

FVC \%: Forced vital capacity. 
Degradation of elastin by elastases leads to the generation of elastin fragments, designated 'elastokines' in keeping with their cytokine-like properties. Generation of elastokines from one of the longest-lived proteins in humans might represent a strong tissue repair signal. Indeed, they exhibit potent chemotactic activity for leukocytes, stimulate fibroblast and smooth muscle cell proliferation, and display as potent a proangiogenic activity as vascular endothelial growth factor. These elastin fragments can also polarize lymphocytes towards a Th-1 response or induce an osteogenic response in smooth muscle cells, and arterial wall calcification [42].

In the present study, $\mathrm{FEV}_{1}$ and $\mathrm{FVC}$ were significantly lower in both obese prehypertensive and obese normotensive women than in normal controls, but there was no statistically significant difference between the prehypertensive obese patients and normotensive obese subjects. These results are consistent with those of Lazarus et al. [43] who reported that increasing BMI is typically associated with reduction in $\mathrm{FEV}_{1}$ and FVC. Also, Bach et al. [44] observed that obesity in dogs caused airflow limitation during the expiratory phase.

The $\mathrm{FEV}_{1} / \mathrm{FVC}$ ratio was lower in both obese prehypertensive and obese normotensive women than in lean normotensive women but did not reach the obstructive limit (below 70\%). Sin et al. [45] reported that an $\mathrm{FEV}_{1} /$ FVC ratio below $70 \%$ (the spirometric signature of airflow obstruction) is not a feature of respiratory disease associated with obesity.

Suzuki et al. [46] suggested that neutrophil elastase contributes to the induction of airway constriction and airway responsiveness in various inflammatory lung diseases with pulmonary neutrophil infiltration, such as chronic obstructive pulmonary disease and possibly bronchial asthma. Nevertheless, the elastase-anti-elastase hypothesis, while popular for a time, is no longer considered the sole explanation for the pathogenesis of emphysema, in the same way that neutrophils are no longer believed to represent the only cellular source of elastolytic enzymes in the lung [47]. Other factors have also been implicated in air space enlargement, including other classes of proteinases (matrix metalloproteinases and cysteine proteinases), oxidative stress, and apoptosis of lung structural cells [48].

TC, TG, and LDL-c were significantly higher in obese prehypertensive women than obese normotensive subjects and healthy controls. This is in agreement with Ganguly et al. [49] who concluded that the prehypertensives had higher levels of TC, TG, and LDL-c than normotensives in a cross-sectional community-based study including 327 prediabetic Omani adults. Similar findings were reported by Liszka et al. [4] and Grotto et al. [50].

Our results showed significantly greater hs-CRP in obese prehypertensive women than obese normotensive women and healthy controls. These results are consistent with those from a study by King et al. [38], who demonstrated significantly higher CRP in prehypertension than normotension.

In addition, we found significant correlations between serum neutrophil elastase and BMI, WC, SBP, DBP, lipid profile and hs-CRP in obese prehypertensive women. These data suggest an association between elastin turnover activity and vascular complications of obesity and hypertension.

One large study of 1,400 patients with cardiovascular disease demonstrated that the serum elastase activity (SEA) was directly proportional to BMI and glucose level and inversely proportional to the triglyceride level. The authors concluded that the remodeling of vessel walls depends not only on the degradation of elastin but also on lipid metabolism [51]. Similarly, SEA was studied as part of an epidemiological study of vascular and cognitive aging (EVA study). SEA was positively and significantly correlated with BMI, systolic blood pressure and triglycerides in both sexes. In multivariate analysis, independent determinants of an increased SEA were age, triglycerides and glucose in men and TGs in women [52]. Paczek et al. [41] also found positive direct correlations between BMI, systolic and diastolic blood pressure and elastase activity.

We observed a significant negative correlation between serum elastase and HDL-c. Our results agree with those of Landi et al. [53], who found significant negative correlations between HDL and HDL2-c and elastase inhibitory capacity in both male atherosclerosis patients and control subjects. Also, elastase-type activity and elastase inhibitory capacity were determined in the sera of atherosclerotic patients, those suffering from ischemic vascular disease located at various sites, and control subjects. There was a significant negative correlation between the inhibitory capacity and HDL-c [54]. Polacek et al. [55] confirmed that both LDL and HDL, two of the major plasma lipoprotein classes, can affect the export from PMN of an elastase that exhibits proteolytic action on apo-B and apo-A-11 in vitro.

Our results showed a significant positive correlation between neutrophil elastase and hs-CRP in obese prehypertensive women. Consistent with these findings, Zureik et al. [56] reported that serum elastase activity was associated with fibrinogen and CRP after a 4 year follow-up in a population of 859 subjects between 59 and 71 years of age. Kakuta et al. [57] suggested that CRP degradation products generated by neutrophil elastase promote neutrophil apoptosis. Cleavage of CRP by neutrophil elastase may offer protection from inflammatory injury.

There was an insignificant negative correlation between the increased level of serum neutrophil elastase 
and pulmonary function tests in obese prehypertensive women, in agreement with Bizeto et al. [58], who found negative correlations between increased neutrophil elastase level and impairment of FVC, $\mathrm{FEV}_{1}$ and the $\mathrm{FEV}_{1} /$ FVC ratio in patients with chronic obstructive pulmonary disease.

From the previous discussion, it seems that elevated serum elastase in obese women could reflect a minor inflammatory state and might be considered an important contributor to the development of prehypertension and possible lung function impairment. Also, the elevation of serum elastase in obesity may explain its association with both hypertension and air flow limitation; additional studies are needed to elucidate the significance of this observation.

\section{Conclusion}

Serum neutrophil elastase concentration is elevated in obese prehypertensive women and its level is correlated with inflammatory markers (high sensitivity C-reactive protein), dyslipidemia and air flow dysfunction.

\begin{abstract}
Abbreviations
NE: Neutrophil elastase; BMI: Body mass index; WC: waist circumference; hsCRP: high sensitivity C- reactive protein; FEV1: forced expiratory volume in one second; FVC: forced vital capacity; TC: total cholesterol; TG: triglyceride; LDL-c: low density lipoprotein cholesterol; HDL-c: high density lipoprotein cholesterol; EDP: elastin-derived protein; SEA: serum elastase activity.
\end{abstract}

\section{Acknowledgements}

The authors thank all sample donors for their contribution to this study and all members of the Endocrinology Unit, Specialized Medical Hospital, Mansoura, Egypt. This paper has been linguistically revised by BiomedES LTD and we appreciate their help in copyediting service.

\section{Author details}

'Internal Medicine Department, Specialized Medical Hospital, Faculty of Medicine, Mansoura University, Mansoura, Egypt. ${ }^{2}$ Clinical Pathology Department, Faculty of Medicine, Mansoura University, Mansoura, Egypt. ${ }^{3}$ Chest Department, Faculty of Medicine, Mansoura University Hospital, Mansoura University, Mansoura, Egypt.

\section{Authors' contributions}

MME drafted the manuscript. EHE and AAM helped to draft the manuscript, AEZ carried out chest examinations and pulmonary function tests, AAE and ERA carried out the laboratory studies, OMS conceived of the study and participated in its design and coordination. All authors read and approved the final manuscript.

\section{Competing interests}

The authors declare that they have no competing interests.

Received: 16 April 2010 Accepted: 19 January 2011

Published: 19 January 2011

\section{References}

1. Chobanian AV, Bakris GL, Black HR, Cushman WC: The seventh report of the joint national committee on prevention, detection, evaluation and treatment of high blood pressure: The JNC 7 Report. JAMA 2003, 289:2560.

2. Greenlund KJ, Groft JB, Mensah GA: Prevalence of heart disease and stroke risk factors in persons with prehypertension in the United States, 1999-2000. Arch - Intern Med 2004, 164:2113.
3. Vasan RS, Larson MG, Leip EP, Kannel WB, Levy D: Assessment of frequency of progression to hypertension in non-hypertensive participants in the Framingham Heart Study: a cohort study. Lacent 2001, 358:1682-1686.

4. Liszka HA, Mainous AG III, King DE, Everett CJ, Egan BM: Prehypertension and cardiovascular morbidity. Ann Fam Med 2005, 3:294-299.

5. Lenfant C, Chobanian AV, Janes DW, Roccella EJ: Seventh report of the joint national committee on the prevention, detection, evaluation and treatment of high blood pressure (JNC7): Resetting the hypertension sail - Hypertension. 2003, 41:1178-1179.

6. Janoff A, Scherer J: Mediators of inflammation in leukocyte lysosomes. IX. Elastinolytic activity in granules of human polymorphonuclear leukocytes. J Exp Med 1968, 128:1137-1155.

7. Belaaouaj AA, McCarthy R, Baumann M, Ley Gaoz TJ, Abraham SN, Shapiro SD: Mice lacking neturophil elastase reveal impaired host defense against gram negative bacterial sepsis. Nat Med 1998, 4:615-618.

8. Garica R, Gusmanil L, Murgia R, Guarnaccia C, Cinco M, Rottini G: Elastase is the only human neutrophil granule protein that alone is responsible for the in vitro killing of borrelia burgdoferi. Infect Immun 1998, 66:1408-1412.

9. Tkalcevic J, Novelli M, phylactides M, Iredale JP, Segal AW, Roes AW, Roes J: Impaired immunity and enhanced resistance to endotoxin in the absence of neutrophil elastase and cathepsin G. Immunity 2000, 12:201-210.

10. Robert $L$, Robert AM, Tacotot B: Elastin-elastase-athersclerosis revisited. Atherosclerosis 1998, 140:81-95.

11. Siedle B, Cisielski S, Murillo R, Löser B, Castro V, Klaas CA, Hucke O, Labahn A, Melzig MF, Merfort I: Sesquiterpene lactones as inhibitors of human neutrophil elastase. Bioorg Med Chem 2002, 10:2855-2861.

12. Bedard M, McClure CD, Schiller NL, Francoeur C, Cantin A, Denis M: Release of interleukin-8, interleukin- 6 and colony stimulating factors by upper airway epithelial cells: implications for cystic fibrosis. Am J Respir cell Mol Biol 1993, 9:455-63.

13. Lee WL, Downey GP, Leukocyte elastase: physiological functions and role in acute lung injury. Am J Respir Crit Care Med 2001, 164:896-904.

14. Turino GM, Seniorrm, Garg BD, Keller S, Levi MM, Mandl I: Serum elastase inhibitor deficiency and $a_{1}$-anti trypsin deficiency in patients with obstructive emphysema. Science 1969, 165:709-711.

15. Gettins PG: Serpin structure, mechanism, and function. Chem Rev 2002, 102:4751-804.

16. Hornebeck W, potazman JP, De Cremoux H, Bellon G, Robert L: Elastasetype activity of human serum: its variation in chronic obstructive lung diseases and atherosclerosis. Clin physiol Biochem 1983, 1:285-592.

17. Khan TZ, Wagener JS, Bost T, Martinez J, Accurso FJ, Riches DW: Early pulmonary inflammation in infants with cystic fibrosis. Am J Respir Crit care Med 1995, 151:1075-1082.

18. Owen CA, Campbell EJ: The cell biology of leukocyte mediated proteolysis. J Leukoc Biol 1999, 65:137-150.

19. Bizbiz L, Bonithon-Kopp C, Ducimetiere' P, Berrc, Alperovitch A, Robert L: Relation of serum elatase activity to ultrasonographyically assessed carotid artery wall lesions and cardiovascular risk factors. The EVA study. Atherolersosis 1996, 120:47-55.

20. Yasmin CMMcEniery, Wallace S, Dakham Z, pulsalkar P, Maki-Petaja K, Ashby MJ, Cockcroft JR, Wilkinson IB: Matrix metalloproteinase-9 (MMP-9), MMp-2 and serum elastase activity are associated with systolic hypertension and arterial stiffness. Arterioscler Thromb Vasc Biol 2005, 25:372.

21. Gardiner PJ: Neutrophil elastase inhibitors. Eur Respir Rev 2002, 12:373-374.

22. Friedewald WT, Levy RT, Fredrickson DS: Estimation of the concentration of low- density lipoprotein cholesterol without the use of preparative ultracentrifuge. Clin Chem 1972, 18:499.

23. Oremek, et al: MTA 1995, 10:273-278.

24. Kimberly MM, Vesper HW, Caudill SP, Cooper GR, Rifai N, Dati F, Myers GL: Standardization of immunoassay for measurement of high-sensitivity $C$ reactive protein phase 1: Evaluation of secondary reference materials. Clin Chem 2003, 49:611-616.

25. Miller MR, Hankinson J, Brusasco V, Burgos F, Casaburi R, Coates A, Crapo R, Enright $P$, van der Grinten $C P$, Gustafsson $P$, Jensen $R$, Johnson DC, Maclntyre N, McKay R, Navajas D, Pedersen OF, Pellegrino R, Viegi G, Wanger J: Standardisation of spirometry. Eur Respir J 2005, 26:319-38.

26. Beilin LJ: Non-pharmacological management of hypertension: Optimal strategies for reducing cavdiovascular risk. J Hypertens 1994, 12:S71-S81. 
27. Yang G, Shu XO, Gao YT, Zhang X, Li H, Zheng W: Impacts of weight change on prehypertension in middle-aged and elderly women. Int $J$ Obes 2007, 31:1818-1825.

28. Okosun IS, Boltri JM, Anochie LK, Chandra KMD: Racial/ethnic differences in prehypertension in American adults: population and relative attributable risk of abdominal obesity. J Hum Hypertens 2004, 18:849-855.

29. Zhang Y, Lee ET, Devereux RB, Yeh J, Best LG, Fabsitz RR, Howard BV: Prehypertension, diabetes and cardiovascular disease risk in a population-based sample: The strong Heart Study. Hypertension 2006, 47:410-414.

30. Leone N, Courbon D, Thomas F, Bean K, Jégo B, Leynaert B, Guize L, Zureik M: Lung function impairment and metabolic syndrome: the critical role of abdominal obesity. Am J Respir Crit Care Med 2009, 179:509-516.

31. Nicoloff $G$, Christova P: Elastin degradation products among obese children with family history of arterial hypertension. Diabetologia croatica 2003, 32-1

32. Nicoloff G, Petrova C, Dimitrova-Laleva P, Christova P: Increased elastin turnover in obese and diabetic children with vascular complications. Diabetologia croatica 2003, 32-2

33. Piwowar A, Knapik-Kordecka M, Warwas M: Concentration of leukocyte elastase in plasma and polymorphouclear neutrophil Extracts in type 2 diabetes. Clin Chem Lab Med 2000, 38:1257-1261.

34. Adeyemi E, Benedicts, Abdulle A: A comparison of plasma polymorphonuclear leucocyte elastase levels in obese and lean individuals. J Int Med Res 1998, 26:252-256.

35. Keeley FW, Alatawi A: Response of aortic elastin synthesis and accumulation to developing hypertension and the inhibitory effect of cochicine on this response. Lab Invest 1991, 64:499-507.

36. Rana JS, Nieuwdorp M, Jukema JW, Kastelein JJ: Cardiovascular metabolic syndrome-interplay of obesity, inflammation, diabetes and coronary heart disease. Diabetes obes Metab 2007, 9:218-232.

37. Chrysohoou C, Pitsavos C, Ponagiotakos DB, Skoumas J, Stefanadis C: Association between prehypertension status and inflammatory markers related to altheosclerotic disease. Am J Hypertens 2004, 17:568-573, The ATTICA Study.

38. King DE, Egan BM, Mainous AG, Geesey ME: Elevation of C-reactive protein in people with prehypertension. J Clin Hypertens 2004, 6:562-568.

39. Mania-pramanik J, potdar SS, Vadigoppula A, Sawant S: Elastase: a predictive matter of inflammation and/or infection. J Clin Lab Anal 2004, 18:153-158.

40. Nicoloff G, Petkova-Botzova M, Baydanoff S: Serum levels of elastin and collagen-derived peptides in children with high risk of atherosclerosis. Int J Obes 1995, 19:120

41. Paczek L, Michalska W, Bartlomiejczyk I: Trypsin, elastase, plasmin and MMP-9 activity in the serum during the human ageing process. Age ageing 2008, 37:318-323.

42. Antonicelli F, Bellon G, Debelle L, Hornebeck W: Elastin- elastases and inflamm-aging. Curr Top Dev Biol 2007, 79:99-155.

43. Lazarus R, Sparrow D, Weiss ST: Effect of obesity and fat distribution on ventillatory function: the normative aging study. Chest 1997, 111:91-98.

44. Bach JF, Rozanski EA, Bedenice D, et al: Association of expiratory airway dysfunction with marked obesity in healthy adult dogs. Am J Vet Res 2007, 68:670-675.

45. Sin DD, Jones Rl, Man SF: Obesity is a risk factor for dyspnea but not for air flow obstruction. Arch Intern Med 2002, 162:1477-1481.

46. Suzuki T, Wang W, Lin JT, Shirato K, Mitsuhashi H, Inoue H: Aerosolized human neutrophil elastase induces airway constriction and hyperresponsiveness with protection by intravenous pretreatment with half- length secretory leukprotease inhibitor. Am J Respir Crit Care Med 1996, 153:1405-11.

47. Parks WC, Shapiro SD: Matrix metalloproteinases in lung biology. Respir Res 2001, 2:10-19.

48. Owen CA: Proteinases and oxidants as targets in the treatment of obstructive pulmonary disease. Proc Am Thorac Soc 2005, 2:373-385.

49. Ganguly SS, Al-Shafaee MA, Bhargava K, Duttagupta KK: Prevalence of prehypertension and associated cardiovascular risk profiles among prediabetic Omani adults. BMC Public Health 2008, 8:108

50. Grotto I, Grossman E, Huerta M, Sharabi Y: Prevalence of prehypertension and associated cardiovascular risk profiles among young Israeli adults. Hypertension 2006, 48:254-272.
51. Bonithon-Kopp C, Touboul PJ, Berr C, Magne C, Ducimetière $P$, et al: Factors of carotid arterial enlargement in a popular aged 59 to 71 years. Stoke 1996, 27:654-660

52. BizBiz L, Bonithon-Kopp C, Ducimetiere P, Berr C, Alper.Ovitch A, Robert L: Relation of serum elastase activity to ultrasonographically assessed carotid artery wall lesions and cardiovascular risk factors. The EVA study Atherosclerosis 1996, 120:47-55.

53. Landi A, Bihari-Varga M, Keller L, Mezey Z, Gruber E: Elastase - type enzymes and their relation to blood lipids in atherosclerotic patients. Atherosclerosis 1992, 93:17-23

54. Bihari-Varga $M$, Keller L, Landi A, Robert L: Elastase-type activity, elastase inhibitory capacity, lipids and lipoproteins in the sera of patients with ischemic vascular disease. Atherosclerosis 1984, 50:273-81.

55. Polacek D, Byrne RE, Fless GM, Scanu AM: In vitro proteolysis of human plasma low density lipoproleins by an elastase released from human blood polymorphonuclear cells. J Biol Chem 1986, 261:2057-2063.

56. Zureik M, Robert L, Courbon D, Touboul PJ, Bizbiz L, Ducimetiere P, Serum elastase activity: serum elastase inhibitors, and occurrence of carotid Atherosclerotic plagues. Circulation 2002, 105:2638-2645.

57. Kakuta J, Aoshiba K, Nagi A: : C-reactive protein products generated by neutrophil elastase promote neutrophil apoptosis. Arch Med Res 2006, 37:456-460.

58. Bizeto L, Mazzolini AB: Ribeiro: Interrelationship between serum and sputum inflammatory mediators in chronic obstructive pulmonary disease. Braz J Med Biol Res 2008, 41:193-198.

Pre-publication history

The pre-publication history for this paper can be accessed here: http://www.biomedcentral.com/1472-6874/11/1/prepub

doi:10.1186/1472-6874-11-1

Cite this article as: El-Eshmawy et al: Elevated serum neutrophil elastase is related to prehypertension and airflow limitation in obese women. BMC Women's Health 2011 11:1.

\section{Submit your next manuscript to BioMed Central and take full advantage of:}

- Convenient online submission

- Thorough peer review

- No space constraints or color figure charges

- Immediate publication on acceptance

- Inclusion in PubMed, CAS, Scopus and Google Scholar

- Research which is freely available for redistribution

Submit your manuscript at www.biomedcentral.com/submit
C Biomed Central 